\title{
Potassium supplying capacity of northeastern Portuguese soils
}

\author{
ESTER A.C. PORTELA \\ Department of Geosciences, University of Trás-os-Montes e Alto Douro, 5000 Vila Real, Portugal
}

Key words: illite, $\mathrm{K}$ release, $\mathrm{K}$ reserve, $\mathrm{K}$ uptake, mica, non-exchangeable $\mathrm{K}$, potassium, ryegrass

\begin{abstract}
In Portugal, the response to $\mathrm{K}$ application is often inconsistent with the Egner-Riehm values for available $\mathrm{K}$. This is partly related to high $\mathrm{K}$ reserves of some soils. Twenty surface soils representative of different parent materials from NE Portugal were studied to determine their K supplying capacity. Continuous cropping with perennial ryegrass permitted the assessment of the relative ability of soils to release non-exchangeable $\mathrm{K}$. Soils were classified in the range of available $\mathrm{K}$ from medium to very high. However, their ability to supply $\mathrm{K}$ in the short and long term are very different. In some soils $\mathrm{K}$ status measured by plant growth does not fall appreciably, whilst others are rapidly exhausted, and $30 \%$ of them are very deficient in $\mathrm{K}$. The supplying capacity varied both with the nature of the parent material and the degree of weathering. The soils deficient in $\mathrm{K}$ are those derived from basic rocks and those with more weathered clay minerals. This is the case of the soils with the largest content of organic matter where the dominant clay minerals were kaolinite and vermiculite. Soils that have the highest capacity for supplying $\mathrm{K}$ are highly micaceous, like those developed from mica schists, phyllites or river alluvium. In fact the amount of $\mathrm{K}$ released from non-exchangeable form is well correlated with the amount of illite in the clay fraction. Soil types and $\mathrm{K}$ buffer power coupled with available $\mathrm{K}$ must be taken into account when planning any application of $\mathrm{K}$.
\end{abstract}

\section{Introduction}

Most of the methods used for determining available $\mathrm{K}$ are based on the extraction of the exchangeable form. The method of EgnerRiehm, which is an approximate measure of exchangeable $\mathrm{K}$, has been systematically used in Portugal. However it has been recognized that exchangeable $\mathrm{K}$ is an indifferent index of $\mathrm{K}$ availability for many soils (Alves, 1968; Alves et al., 1979; Cooke, 1982). One reason for this partial failure of the exchangeable $K$ to account for uptake is the release of $K$ from a nonexchangeable form during cropping.

The mineralogical composition of the soil has an enormous influence on $\mathrm{K}$ dynamics. Total soil $\mathrm{K}$ reserves are generally large, although the distribution of $\mathrm{K}$ forms differs from soil to soil as a function of the dominant minerals present. Knowing soil $\mathrm{K}$ reserves and distribution of $\mathrm{K}$ forms coupled with mineralogical data should reveal more about the status of soil $\mathrm{K}$ in the major soil types of the region. Although the release of non-exchangeable $\mathrm{K}$ depends on the soil mineralogy there have been few successful attempts to relate it to mineralogical composition of soils.

The main objective of this study is the assessment of the $K$ supplying power of soils of $\mathrm{NE}$ (Trás-os-Montes region) Portugal. The relative ability of soils to release non-exchangeable $\mathrm{K}$ was evaluated by biological and chemical methods. In addition, soils were examined by $X$ ray diffraction to determine whether differences could be established in their mineralogical composition. 


\section{Materials and methods}

\section{Soil analysis}

Soil samples were taken from the $0-20-\mathrm{cm}$ surface layer of 20 sites of NE Portugal. The physico-chemical characteristics of the soil samples are given in Table 1. The soils represented the major soil types and were associated with a wide range of parent materials (Table 2) and climatic conditions. Most of the soils fall in the range of available $K$ regarded as 'medium', 50 $100 \mathrm{mg} \mathrm{kg}^{-1}$ (Table 3 ). The soils received little or no $\mathrm{K}$ fertilizers up to the time of sampling. Only soil 9 had been limed, in the previous year.

Mineralogical analyses was done on the $<2 \mu \mathrm{m}$ and $2-20 \mu \mathrm{m}$ soil fractions by X-ray diffraction. The methodology for preparing soil samples and estimation of mineral abundance is described by Silva (1983). Estimates of the amount of mineral specimens present should be regarded as semi-quantitative.

The 20 soil samples were each analyzed for several forms of soil $K$. The $K$ concentration in soil solution was obtained by displacement procedure (Adams, 1974); exchangeable K was determined with $1 \mathrm{~N} \mathrm{NH}_{4} \mathrm{OAc}(\mathrm{pH} \mathrm{7)} ; 1 \mathrm{~N}$ boiling $\mathrm{HNO}_{3}$ was used to determine the reserve of non-exchangeable $\mathrm{K}$ and $\mathrm{HF}$ digestion to extract total K (Knuden et al., 1982); available $\mathrm{K}$ was extracted with $\mathrm{NH}_{4}$-lactate-acetic acid $(\mathrm{pH}$ 3.75). Analyses were made on air dried soils, $\mathrm{K}$ in the extracts was measured with an EEL flame photometer.

$\mathrm{K}$ buffer power was given by the slope of the line relating the change in exchangeable $K$ $(\triangle \mathrm{Kex})$ and the change of the $\mathrm{K}$ in soil solution $(\triangle \mathrm{Ks})$. Buffer curves of soils were obtained by adding, in the laboratory, graded doses of $\mathrm{KCl}$ to subsamples of $1 \mathrm{~kg}$ of soil. After treatment, the soils were maintained at a room temperature of $18^{\circ} \mathrm{C} \pm 2^{\circ} \mathrm{C}$ during 21 days at $33 \mathrm{kPa}$ moisture tension. At the end of this period soils were analyzed for exchangeable $\mathrm{K}$ and solution $\mathrm{K}$. The resulting plots showed an approximately linear relationship, and buffer power was determined as $\triangle \mathrm{Kex} / \Delta \mathrm{Ks}$.

\section{Exhaustion experiment}

Soils were air-dried and passed through a 2-mm sieve. One $\mathrm{kg}$ of each soil was placed in plastic

Table 1. Chemical and physical properties of the soils

\begin{tabular}{|c|c|c|c|c|c|c|c|c|c|c|c|c|}
\hline \multirow[t]{2}{*}{ Soil } & \multicolumn{3}{|c|}{ Particle size (\%) } & \multirow{2}{*}{$\begin{array}{l}\text { Organic } \\
\text { matter } \\
(\%)\end{array}$} & \multicolumn{2}{|c|}{$\mathrm{pH} 1: 2.5$} & \multicolumn{6}{|c|}{ Exchangeable cations $\left(\mathrm{cmol}_{\mathrm{c}} \mathrm{kg}^{-1}\right)$} \\
\hline & $>20 \mu \mathrm{m}$ & $2-20 \mu \mathrm{m}$ & $<2 \mu \mathrm{m}$ & & $\mathrm{H}_{2} \mathrm{O}$ & $\mathrm{KCl}$ & $\mathrm{Ca}$ & $\mathrm{Mg}$ & $\mathrm{K}$ & $\mathrm{Na}$ & Ac & $\mathrm{CECe}$ \\
\hline 1 & 79.5 & 13.3 & 7.2 & 1.0 & 5.5 & 4.2 & 1.23 & 0.17 & 0.18 & 0.03 & 1.34 & 2.95 \\
\hline 6 & 78.2 & 15.3 & 6.5 & 0.5 & 5.5 & 3.8 & 1.39 & 0.11 & 0.11 & 0.03 & 0.97 & 2.61 \\
\hline 15 & 79.8 & 11.5 & 8.7 & 3.0 & 5.4 & 4.3 & 1.35 & 0.40 & 0.10 & 0.07 & 0.86 & 2.78 \\
\hline 9 & 73.9 & 15.5 & 10.6 & 0.9 & 6.1 & 5.0 & 3.05 & 0.27 & 0.17 & 0.03 & 0.16 & 3.65 \\
\hline 10 & 74.7 & 14.8 & 10.5 & 0.6 & 5.1 & 3.9 & 4.09 & 1.58 & 0.16 & 0.07 & 1.70 & 7.60 \\
\hline 2 & 54.4 & 37.7 & 8.6 & 0.6 & 6.5 & 3.8 & 7.66 & 2.20 & 0.10 & 0.08 & 0.70 & 10.74 \\
\hline 4 & 57.8 & 32.4 & 9.8 & 0.7 & 7.3 & 5.8 & 8.07 & 0.54 & 0.12 & 0.08 & 0.12 & 8.93 \\
\hline 8 & 78.5 & 12.7 & 8.8 & 0.5 & 5.7 & 3.9 & 4.34 & 1.81 & 0.21 & 0.07 & 1.90 & 8.33 \\
\hline 17 & 63.3 & 26.9 & 9.8 & 0.7 & 5.5 & 4.1 & 2.14 & 0.20 & 0.25 & 0.03 & 0.86 & 3.48 \\
\hline 11 & 61.7 & 30.3 & 8.0 & 1.0 & 5.5 & 3.9 & 0.71 & 0.18 & 0.19 & 0.03 & 1.39 & 2.50 \\
\hline 18 & 59.6 & 30.3 & 10.1 & 1.1 & 5.5 & 3.8 & 3.52 & 1.07 & 0.16 & 0.05 & 1.20 & 6.00 \\
\hline 19 & 61.5 & 27.5 & 11.0 & 1.4 & 5.4 & 4.0 & 1.92 & 0.33 & 0.43 & 0.05 & 1.05 & 3.78 \\
\hline 20 & 63.7 & 24.0 & 12.3 & 0.8 & 5.3 & 3.8 & 1.73 & 0.43 & 0.16 & 0.04 & 1.24 & 3.60 \\
\hline 12 & 68.4 & 16.1 & 15.5 & 1.8 & 6.5 & 5.1 & 5.64 & 5.60 & 0.21 & 0.04 & 0.16 & 11.65 \\
\hline 13 & 54.3 & 18.4 & 27.3 & 1.7 & 6.4 & 4.5 & 11.06 & 6.00 & 0.11 & 0.18 & 0.23 & 17.58 \\
\hline 14 & 60.8 & 26.3 & 12.9 & 1.1 & 6.1 & 4.3 & 5.44 & 2.72 & 0.08 & 0.09 & 0.30 & 8.63 \\
\hline 5 & 59.4 & 31.8 & 8.8 & 6.0 & 5.3 & 3.9 & 1.48 & 0.28 & 0.15 & 0.07 & 3.11 & 5.09 \\
\hline 16 & 71.7 & 20.5 & 7.8 & 12.5 & 4.7 & 4.1 & 0.40 & 0.30 & 0.18 & 0.05 & 3.11 & 4.04 \\
\hline 7 & 70.1 & 19.1 & 10.8 & 0.7 & 5.2 & 4.1 & 1.01 & 0.18 & 0.11 & 0.03 & 0.87 & 2.20 \\
\hline 3 & 39.5 & 47.7 & 12.8 & 1.4 & 7.1 & 6.1 & 6.40 & 1.13 & 1.13 & 0.14 & 0.14 & 8.94 \\
\hline
\end{tabular}

$\mathrm{Ac}-$ exchangeable acidity; $\mathrm{CECe}$ - effective cation exchange capacity. 
Table 2. Soils, taxonomy, parent materials and mineralogy of clay and silt fractions

\begin{tabular}{|c|c|c|c|c|c|c|c|c|c|c|c|c|c|c|}
\hline \multirow[t]{3}{*}{ Soil } & \multirow[t]{3}{*}{ Soil taxonomy } & \multirow[t]{3}{*}{ Parent material } & \multicolumn{12}{|c|}{ Mineralogy } \\
\hline & & & \multicolumn{6}{|c|}{$<2 \mu \mathrm{m}$} & \multicolumn{6}{|c|}{$2-20 \mu \mathrm{m}$} \\
\hline & & & $\mathrm{K}$ & I & $\mathrm{M}$ & V & $\mathrm{I}-\mathrm{V}$ & $\mathrm{Cl}-\mathrm{V}$ & $\mathrm{K}$ & Mi & $\mathbf{M}$ & $\mathrm{V}$ & $\mathrm{Cl}$ & $\mathrm{O}$ \\
\hline 1 Carrazeda & Humic cambisol & Alkaline granites & 4 & 1 & 1 & 1 & - & - & 4 & 2 & - & - & - & 1 \\
\hline 6 Peredo & Distric cambisol & Alkaline granites & 3 & 2 & - & 2 & - & - & 2 & 3 & - & - & - & 2 \\
\hline $15 \mathrm{~S}$. André & Humic cambisol & Alkaline granites & 3 & 1 & - & 2 & - & - & 1 & 1 & - & 2 & - & 4 \\
\hline 9 Malhadas & Aplic alisol & Calcic granites & 3 & 1 & - & 1 & 1 & - & 2 & 2 & - & - & - & 2 \\
\hline 10 Miranda & Distric cambisol & Calcic granites & 2 & 1 & 3 & - & - & 1 & 2 & 2 & 2 & - & - & 2 \\
\hline 2 Carrascal & Eutric cambisol & Mica schists & 3 & 2 & 1 & 2 & - & - & 3 & 2 & - & 1 & - & 1 \\
\hline 4 Muxagata & Aplic luvisol & Mica schists & 3 & 2 & 2 & 1 & - & - & 2 & 3 & - & 1 & - & 1 \\
\hline 8 Sendim & Eutric leptosol & Mica schists & 3 & 3 & - & 1 & - & - & 2 & 2 & - & - & - & 2 \\
\hline 17 V. Real & Distric cambisol & Mica schists & 3 & 1 & - & 1 & - & 1 & 3 & 2 & - & 1 & - & 1 \\
\hline 11 Vimioso & Distric cambisol & Phyllites & 3 & 3 & - & 1 & - & - & 1 & 3 & - & 1 & - & 3 \\
\hline 18 Alfandega & Distric cambisol & Phyllites & 3 & 3 & - & 1 & - & - & 2 & 3 & - & 1 & - & 1 \\
\hline 19 Curopos & Distric cambisol & Phyllites & 2 & 2 & - & 2 & - & - & 2 & 2 & - & 2 & - & 1 \\
\hline 20 Mirandela & District cambisol & Phyllites & 2 & 3 & - & 1 & 1 & - & 2 & 2 & - & 2 & - & 1 \\
\hline 12 Bragança & Chromic luvisol & Peridotites & 1 & - & 2 & - & - & 4 & - & 1 & 1 & - & 2 & 4 \\
\hline 13 Izeda & Chromic vertisol & Amphibole schists & 1 & - & 4 & 1 & - & - & - & 1 & 4 & - & - & 1 \\
\hline 14 Frieira & Chromic leptosol & Amphibole schists & 2 & 1 & - & 1 & - & 4 & 2 & 1 & - & - & 3 & - \\
\hline 5 Reboredo & Humic cambisol & Schists and quartzites & 3 & 1 & - & 3 & - & - & 2 & 2 & - & 1 & - & 2 \\
\hline 16 Montalegre & Humic cambisol & Hornfelses & 3 & 1 & - & 1 & $2^{a}$ & - & 2 & 1 & - & 2 & - & 2 \\
\hline 7 Sanhoane & Aplic alisol & Coarse sediments & 4 & 1 & - & 1 & - & - & 2 & 2 & - & - & - & 3 \\
\hline 3 Vilariça & Eutric fluvisol & River alluvium & 2 & 3 & 1 & - & - & 2 & 2 & 3 & 1 & - & - & 2 \\
\hline
\end{tabular}

$\mathrm{K}$ - kaolinite; I-illite; M-montmorillonite; V-vermiculite; I-V - interlayered illite-vermiculite; Cl-V-interlayered chloritevermiculite; $\mathrm{Cl}$ - chlorite; $\mathrm{O}$ - others

${ }^{a} \mathrm{Al}$-vermiculite

$1=<10 \% ; 2=10-20 \% ; 3=20-40 \% ; 4=40-60 \%$.

Table 3. Forms of potassium and buffer power of the soils

\begin{tabular}{|c|c|c|c|c|c|c|}
\hline Soil & $\begin{array}{l}\text { Soil solution K } \\
\left(\mathrm{mg} \mathrm{L}^{-1}\right)\end{array}$ & $\begin{array}{l}\text { Exchangeable } \mathrm{K} \\
\left(\mathrm{mg} \mathrm{kg}^{-1}\right)\end{array}$ & Buffer power & $\begin{array}{l}\text { K-reserve } \\
\left(\mathrm{mg} \mathrm{kg}^{-1}\right)\end{array}$ & $\begin{array}{l}\text { Total K } \\
\left(\mathrm{g} \mathrm{kg}^{-1}\right)\end{array}$ & $\begin{array}{l}\text { Available } \mathrm{K}_{2} \mathrm{O} \\
\left(\mathrm{mg} \mathrm{kg}^{-1}\right)\end{array}$ \\
\hline 1 & 22.0 & 70 & 2.3 & 336 & 47.2 & 123 \\
\hline 6 & 7.0 & 43 & 2.1 & 1528 & 23.2 & 78 \\
\hline 15 & 5.2 & 39 & 1.0 & 335 & 44.8 & 91 \\
\hline 9 & 7.8 & 66 & 1.7 & 644 & 26.8 & 96 \\
\hline 10 & 14.1 & 62 & 3.2 & 534 & 31.6 & 104 \\
\hline 2 & 2.7 & 39 & 2.9 & 1455 & 29.0 & 65 \\
\hline 4 & 4.2 & 47 & 2.3 & 632 & 27.2 & 80 \\
\hline 8 & 8.2 & 82 & 2.0 & 2703 & 25.6 & 106 \\
\hline 17 & 15.0 & 98 & 1.7 & 698 & 28.0 & 159 \\
\hline 11 & 12.5 & 74 & 1.5 & 523 & 29.6 & 147 \\
\hline 18 & 10.5 & 62 & 2.4 & 713 & 33.2 & 135 \\
\hline 19 & 51.0 & 168 & 1.9 & 301 & 30.0 & 312 \\
\hline 20 & 12.0 & 62 & 1.7 & 435 & 32.0 & 100 \\
\hline 12 & 8.6 & 82 & 6.0 & 191 & 3.6 & 131 \\
\hline 13 & 0.4 & 43 & 6.3 & 78 & 4.0 & 81 \\
\hline 14 & 5.9 & 31 & 5.3 & 51 & 1.2 & 55 \\
\hline 5 & 5.2 & 59 & 1.3 & 187 & 14.2 & 90 \\
\hline 16 & 6.5 & 70 & 0.7 & 581 & 13.4 & 90 \\
\hline 7 & 4.3 & 43 & 1.9 & 239 & 10.4 & 85 \\
\hline 3 & 92.0 & 440 & 5.1 & 2067 & 34.6 & 676 \\
\hline
\end{tabular}


pots and cropped in triplicate in the greenhouse. Those with $\mathrm{pH}\left(\mathrm{H}_{2} \mathrm{O}\right) \leqslant 5.5$ were limed with $\mathrm{CaCO}_{3}$. A basal nutrient solution (Portela, 1989) was thoroughly mixed with the soils before seeding. A $250 \mathrm{mg}$ addition of $\mathrm{K}$ was made to half of the pots. Soils were seeded with Lolium perenne, cv. 'Victorian', to obtain an approximate plant density of 100 plants per pot. Distilled water was added daily to bring the soils to $33 \mathrm{kPa}$ moisture tension. Dry matter production was measured at intervals by cutting the grass $3 \mathrm{~cm}$ above the soil. After each cutting, all pots received $100 \mathrm{mg} \mathrm{N}$ and $100 \mathrm{mg} P$, and those pots treated with $\mathrm{K}$ received $50 \mathrm{mg} \mathrm{K}$. After a period of 5 months all pots were dressed with the same basal nutrient solution given at the beginning of the experiment. The number of cuttings varied according to the soil. The last harvest was taken when a response to $\mathrm{K}$ was first observed. Soils that never responded to $K$ application were harvested on the 375 th day of growth. Soils were separated from the roots and analyzed for exchangeable K. Plant material was dried at $65^{\circ} \mathrm{C}$ for 48 hours, weighed, ground and digested in nitric-percloric mixture. $\mathrm{K}$ was determined by flame photometry.

\section{Results}

Available $\mathrm{K}$ (Table 3 ) is well correlated with soil solution $\mathrm{K}(\mathrm{r}=0.978, p<0.001)$ and with exchangeable $\mathrm{K}(\mathrm{r}=0.991, p<0.001)$. Thus the relative merits of any of these indexes are the same. The buffer power of soils are generally low, particularly those with the highest content of organic matter.

The results of the exhaustion experiment are summarized in Table 4 . The data listed refer to the pots which have not been fertilized with $\mathrm{K}$. If $K$ concentration in plants at the first harvest is taken as a measure of $\mathrm{K}$ supply, this is poorly correlated with available $\mathrm{K}(\mathrm{r}=0.629, p<0.01)$, and this index only explains $40 \%$ of variation. The $\mathrm{K}$ concentration of the first cutting is, for some soils, lower than the level considered sufficient for optimum growth of ryegrass $(16 \mathrm{~g}$ $\mathrm{kg}^{-1}$ by Cook, 1982). Surprisingly, out of the 10

Table 4. Dry matter yield of Lolium perenne, $\mathrm{K}$ concentration of the first and the last cuttings, $\mathrm{K}$ uptake per kg of soil, fall in exchangeable $\mathrm{K}$ and release of non-exchangeable $\mathrm{K}$

\begin{tabular}{|c|c|c|c|c|c|c|c|c|}
\hline \multirow[t]{2}{*}{ Soil } & \multirow{2}{*}{$\begin{array}{l}\text { No of } \\
\text { cuttings }\end{array}$} & \multirow{2}{*}{$\begin{array}{l}\text { Dry } \\
\text { matter } \\
(\mathrm{g})\end{array}$} & \multicolumn{2}{|c|}{$\mathrm{K}$ concentration $\left(\mathrm{g} \mathrm{kg}^{-1}\right)$} & \multirow{2}{*}{$\begin{array}{l}\text { K uptake } \\
\left(\mathrm{mg} \mathrm{kg}^{-1}\right)\end{array}$} & \multirow{2}{*}{$\begin{array}{l}\text { Fall in } \\
\text { exchangeable } \mathrm{K} \\
\left(\mathrm{mg} \mathrm{kg}^{-1}\right)\end{array}$} & \multicolumn{2}{|c|}{ Release of non-exchangeable $\mathrm{K}^{\mathrm{a}}$} \\
\hline & & & $1^{\text {st }} \mathrm{cut}$ & last cut & & & $\left(\mathrm{mg} \mathrm{kg}^{-1}\right)$ & $(\%)$ \\
\hline 1 & 7 & 27 & 18.6 & 4.6 & 282 & 55 & 227 & 80 \\
\hline 6 & 7 & 27 & 11.6 & 9.1 & 424 & 16 & 408 & 96 \\
\hline 15 & 3 & 16 & 8.4 & 4.7 & 97 & 16 & 81 & 84 \\
\hline 9 & 6 & 23 & 13.0 & 5.7 & 228 & 35 & 193 & 85 \\
\hline 10 & 15 & 49 & 21.4 & 4.9 & 728 & 39 & 689 & 95 \\
\hline 2 & 15 & 52 & 16.2 & 17.1 & 941 & 16 & 925 & 98 \\
\hline 4 & 15 & 50 & 16.8 & 8.6 & 982 & 16 & 966 & 98 \\
\hline 8 & 15 & 52 & 37.7 & 12.5 & 1275 & 43 & 1232 & 97 \\
\hline 17 & 8 & 31 & 24.5 & 7.2 & 499 & 70 & 429 & 86 \\
\hline 11 & 8 & 32 & 24.4 & 10.2 & 618 & 39 & 579 & 94 \\
\hline 18 & 15 & 55 & 32.8 & 10.2 & 1246 & 31 & 1215 & 98 \\
\hline 19 & 8 & 34 & 31.2 & 12.4 & 752 & 105 & 647 & 86 \\
\hline 20 & 15 & 54 & 17.0 & 6.7 & 884 & 35 & 849 & 96 \\
\hline 12 & 6 & 26 & 18.2 & 4.9 & 278 & 39 & 239 & 86 \\
\hline 13 & 2 & 10 & 5.1 & 3.6 & 43 & 4 & 39 & 91 \\
\hline 14 & 2 & 10 & 7.4 & 3.7 & 51 & 4 & 47 & 92 \\
\hline 5 & 2 & 11 & 5.6 & 3.4 & 50 & 8 & 42 & 84 \\
\hline 16 & 2 & 12 & 4.3 & 2.5 & 41 & 16 & 25 & 61 \\
\hline 7 & 2 & 11 & 6.3 & 5.0 & 61 & 8 & 53 & 87 \\
\hline 3 & 15 & 54 & 40.2 & 16.3 & 1577 & 402 & 1175 & 75 \\
\hline
\end{tabular}

\footnotetext{
${ }^{a}$ Non-exchangeable $\mathrm{K}$ was calculated from total $\mathrm{K}$ uptake by grass minus fall in exchangeable $\mathrm{K}$
} 
soils classified as 'medium', 8 are $\mathrm{K}$ deficient, particularly soils $5,7,13,14,15$ and 16 , which showed a prompt response to $\mathrm{K}$ application. The remainder were maintained under cropping until 4 to 12 months of growth. In these soils the percentage of $\mathrm{K}$ released from non-exchangeable form is $\geqslant 75 \%$.

Figure 1 gives some typical curves of the cumulative uptake of $\mathrm{K}$ by ryegrass selected from soils that have the same initial exchangeable $\mathrm{K}$. The rate of $\mathrm{K}$ uptake can be obtained from the slope of the curve when the cumulative
$\mathrm{K}$ uptake is plotted against days of growth. The amount of $\mathrm{K}$ absorbed by the crop is approximately linearly related with the growth period in all soils. So it is possible to fit regression equations to the observed values (Table 5). If we consider the percentage of non-exchangeable $\mathrm{K}$ released from most of the soils (Table 4), it can be seen that the rate of $\mathrm{K}$ uptake is approximately the same as the rate of $K$ released. It is possible to distinguish two rates of $\mathrm{K}$ release in soils that have been maintained until the 15 th cut (Fig. 1). One initial rate applies to 5 months of

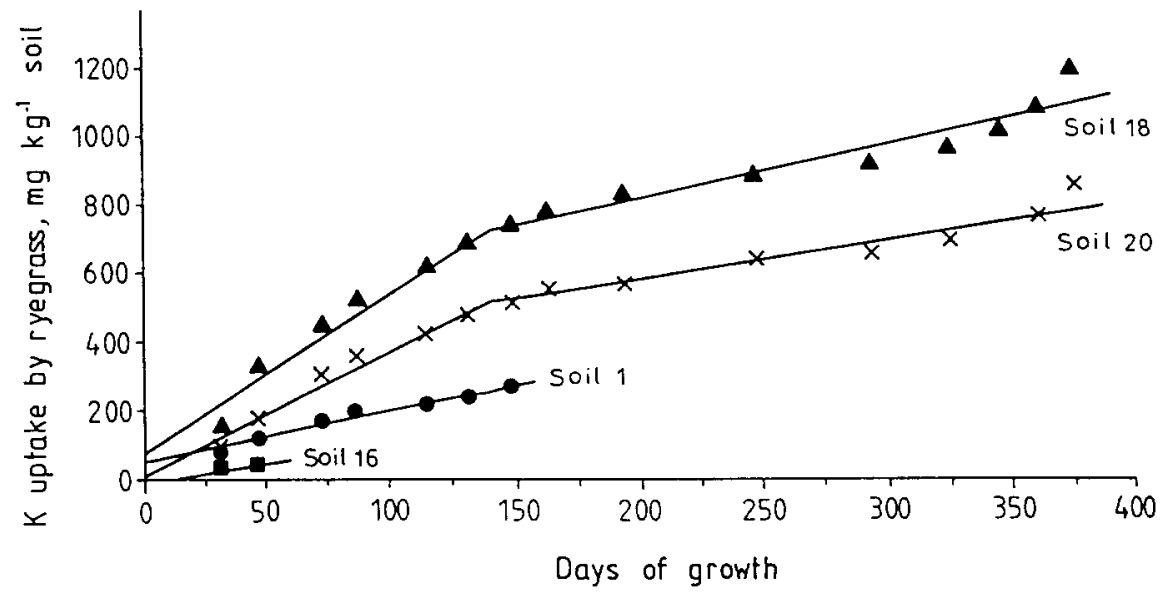

Fig. 1. Cumulative $\mathbf{K}$ uptake by ryegrass in four soils, with similar initial exchangeable $\mathbf{K}$.

Table 5. Regression equations and regression coefficients for the relation between cumulative $\mathrm{K}$ uptake and days of growth of the soils maintained under 3 to 12 months cropping

\begin{tabular}{rclll}
\hline Soil & $\begin{array}{l}\text { No of } \\
\text { cuttings }\end{array}$ & $\begin{array}{l}\text { Regression equation } \\
\text { of initial observations }\end{array}$ & $\mathrm{r}^{2}$ & $\begin{array}{l}\text { Regression equations } \\
\text { of last observations }\end{array}$ \\
\hline 1 & 7 & $\mathrm{y}_{1}=1.54 \mathrm{x}_{1}+45.8$ & 0.963 & - \\
6 & 6 & $\mathrm{y}_{1}=2.85 \mathrm{x}_{1}-17.1$ & 0.979 & - \\
9 & 6 & $\mathrm{y}_{1}=1.46 \mathrm{x}_{1}+25.4$ & 0.973 & - \\
10 & 15 & $\mathrm{y}_{1}=5.06 \mathrm{x}_{1}-62.2$ & 0.978 & $\mathrm{y}_{2}=0.75 \mathrm{x}_{2}+379$ \\
2 & 15 & $\mathrm{y}_{1}=4.43 \mathrm{x}_{1}+30.3$ & 0.982 & $\mathrm{y}_{2}=1.49 \mathrm{x}_{2}+256$ \\
4 & 15 & $\mathrm{y}_{1}=3.91 \mathrm{x}_{1}+17.6$ & 0.988 & $\mathrm{y}_{2}=1.34 \mathrm{x}_{2}+364$ \\
8 & 15 & $\mathrm{y}_{1}=4.73 \mathrm{x}_{1}+26.6$ & 0.982 & $\mathrm{y}_{2}=1.87 \mathrm{x}_{2}+408$ \\
17 & 8 & $\mathrm{y}_{1}=2.57 \mathrm{x}_{1}+56.0$ & - & 0.937 \\
11 & 8 & $\mathrm{y}_{1}=3.48 \mathrm{x}_{1}+12.7$ & 0.977 & - \\
18 & 15 & $\mathrm{y}_{1}=6.43 \mathrm{x}_{1}-10.2$ & 0.983 & - \\
19 & 8 & $\mathrm{y}_{1}=3.85 \mathrm{x}_{1}+80.1$ & 0.963 & $\mathrm{y}_{2}=1.67 \mathrm{x}_{2}+475$ \\
20 & 15 & $\mathrm{y}_{1}=5.17 \mathrm{x}_{1}+68.2$ & 0.978 & - \\
12 & 6 & $\mathrm{y}_{1}=1.73 \mathrm{x}_{1}+42.0$ & 0.988 & $\mathrm{y}_{2}=1.25 \mathrm{x}_{2}+419$ \\
3 & 15 & $\mathrm{y}_{1}=6.99 \mathrm{x}_{1}+12.8$ & 0.943 & - \\
\hline
\end{tabular}

${ }^{a}$ This refers to the first 6 to 8 cuttings.

${ }^{\mathrm{b}}$ This refers to the last 8 cuttings. 
growth, and a second rate applies to the remaining period. In Table 5 these rates $\left(\mathrm{mg} \mathrm{kg}^{-1}\right.$ day $^{-1}$ ) are represented by the angular coefficient of the two regression equations, $y_{1}$ and $y_{2}$ respectively. The first rate corresponds to a higher amount of $\mathrm{K}$ diffused from interlayer position, probably from $\mathrm{K}$ fixed close to the edges of clay mineral, and a second rate of release of $\mathrm{K}$, which has to diffuse from the core of the micaceous minerals (Sinclair, 1979).

It is evident that some soils are more rapidly exhausted (soils 1, 6, 9, 12 and 17), but others (soils 2, 3, 4, 8, 18 and 20) continue to release $\mathrm{K}$ at an appreciable rate for a very long time. It seems that soils with an initial rate of release $\geqslant 3.5 \mathrm{mg} \mathrm{kg}^{-1} \mathrm{day}^{-1}$ could be considered as good $\mathrm{K}$ suppliers.

As shown in Table 2 the mineralogy of the clay and silt fractions depends on the nature of parent material from which the soil is derived. Similarly, the total $\mathrm{K}$ content of the soils is connected with the parent material and the mineralogy. Correlations were sought between the estimates of clay mineral constituents of the soils and the values for non-exchangeable $K$ released by intensive cropping (Table 4 ). Since the mineralogical analyses of the soils are not quantitative estimates of mineral abundance, some simplification is necessary in order to relate the uptake of non-exchangeable $\mathrm{K}$ and miner- alogy. So, a mean value of the ranges given in the footnote of Table 2 was taken. The simplification allows some assessment of the variation between soils. The best correlation $(r=0.822$, $p<0.001$ ) was achieved between non-exchangeable $\mathrm{K}$ uptake and the percentage of illite in soil (Fig. 2). Adding a term for the percentage of mica from the silt fraction did not improve significantly the correlation. Although some studies demonstrated significant $\mathrm{K}$ release from the silt fraction during cropping (Doll et al., 1965; Feigenbaum and Levy, 1977), the influence of this fraction is not evident from this study. Inspection of the deviations from the regression showed that a large portion of the variation was due to a few soils, namely soils 2,4 and 10 . When the results from these three soils were omitted the correlation was improved ( $r=0.903$, $p<0.001)$ and only $19 \%$ of the variation remained unaccounted for. As shown in Table 5, these three soils have an appreciable rate of $K$ release, if only the percentage of illite is considered. Table 2 shows that besides the presence of illites, soils 2, 4 and 10 also have certain amounts of montmorillonite. Rich (1968), suggested that the combined presence of illites and montmorillonite may promote the release of $\mathrm{K}$ to plants. Niederbudde and Fischer (1980) studied this phenomenon with pure specimens and reached the conclusion that the presence of smectites

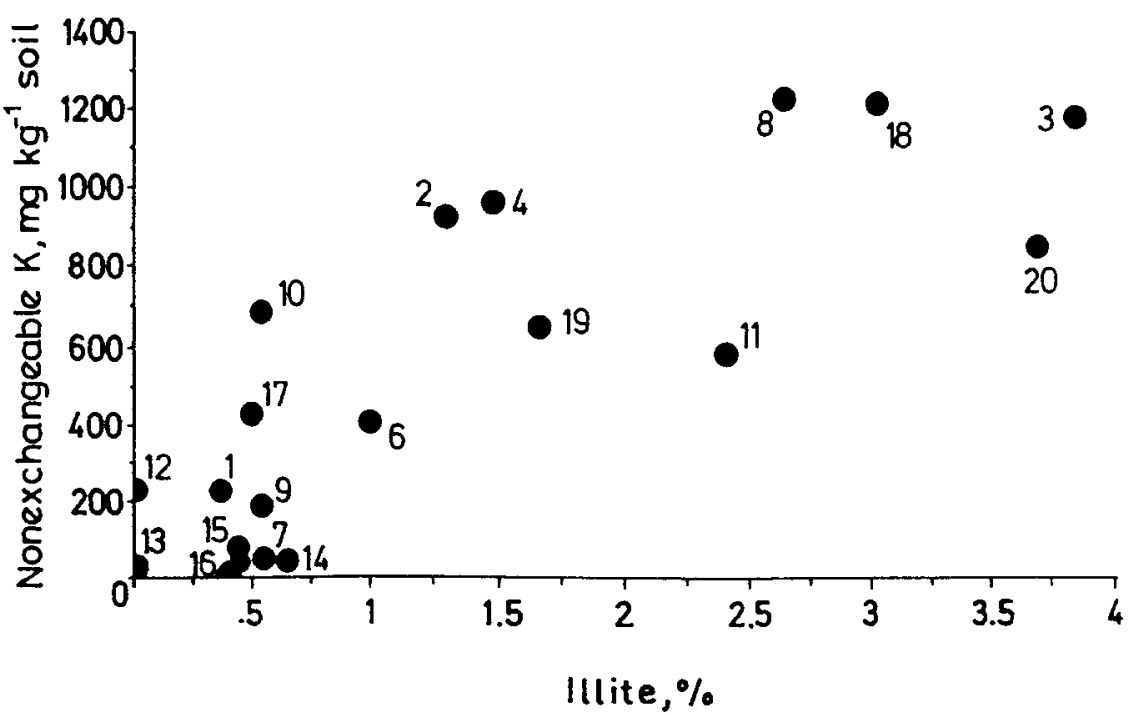

Fig. 2. Relationship between the percentage of illite in soil and release of non-exchangeable K. 
helped to maintain $\mathrm{K}$ in solution at a lower level. Thus the amount of $\mathrm{K}$ diffused from interlayer position was higher. The results from this study suggest that a good $\mathrm{K}$ supplier, illite, combined with a mineral that keeps low $\mathrm{K}$ in soil solution, montmorillonite, would enhance the $K$ release from non-exchangeable form.

The $\mathrm{K}$ reserves (extraction with $\mathrm{HNO}_{3}$ ) were plotted against the non-exchangeable $\mathrm{K}$ absorbed by the crop. The correlation $(r=0.678$, $p<0.001$ ) between them revealed that the method of boiling $\mathrm{HNO}_{3}$ only explains $46 \%$ of variance among soils. In fact, there were some discrepancies. For example, in soils $6,9,15$ and 16 the $\mathrm{HNO}_{3}$ extracted a large amount of $\mathrm{K}$ when compared with $\mathrm{K}$ released by exhaustive cropping and underestimated non-exchangeable $\mathrm{K}$ in soils 4,18 and 20 .

\section{Discussion}

Soils from mountainous areas of NE Portugal, 1000 to $1450 \mathrm{~mm}$ of rainfall and classified as Humic cambisols (soils 1, 5, 15 and 16) show the highest degree of weathering. Gibsite, which is reported to be common, in upper and subsurface horizons of such soils (Silva, 1983), was not detected in the surface horizons of the soils studied. However, there is a high percentage of kaolinite and the presence of vermiculite and/or Al-vermiculite in the clay fraction, which indicates a high degree of weathering. These soils release small amounts of $K$, in spite of the high content of total $\mathrm{K}$ in the soils, particularly in soils 1 and 15 (Table 4). Obviously, in soils developed from alkaline granites the $\mathrm{K}$ in bearing minerals is very tightly held in feldspars and micas of coarser fractions. In addition, those with the highest percentage of organic matter (soils 5, 15 and 16) are very $\mathrm{K}$ deficient and gave a prompt response to $\mathrm{K}$ application. The low $\mathrm{K}$ buffer power of these soils might also be responsible for their limited $\mathrm{K}$ supply, due to their high susceptibility to $\mathrm{K}$ leaching. Fertilizer $\mathrm{K}$ recommendations in these soils should compensate for their low $\mathrm{K}$ buffer power and for the high precipitation occurring in these areas.

A second group of soils, developed on basic rocks (soils 12,13 and 14 ), have low $\mathrm{K}$ reserves due to low content of $\mathrm{K}$ bearing minerals. However, as they have higher $\mathrm{K}$ buffer power than any other group of soils, the $\mathrm{K}$ is less susceptible to leaching.

The largest and most representative group of soils in Trás-os-Montes are Distric and Eutric cambisols. They are derived either from mica schists or phyllites, are less weathered, and have an appreciable percentage of micaceous minerals in both clay and silt fractions (soils 2, 4, 8, 11, $17,18,19$ and 20). This group releases an extremely high percentage of $\mathrm{K}$ from non-exchangeable form, with an initial rate of $\mathrm{K}$ release of 2.6 to $6.4 \mathrm{mg} \mathrm{kg}^{-1} \mathrm{day}^{-1}$. The only Fluvisol studied (soil 3 ) behaved similarly to soil 18 , however its rate of release was higher in the second stage. In soils derived from alluvial material, the $\mathrm{K}$ is less tightly held, and, therefore, more readily available to plants (Binnie and Barber, 1964; Talibudeen and Dey, 1968).

It is difficult to use data obtained in pot trials for assessing the field situation since the volume of soil from which $K$ is removed by plants is much smaller in pots. Besides, as shown by Seffens (1986), the test plant, ryegrass, has a great potential for exploiting soil $\mathrm{K}$ from the non-exchangeable pool. The high density of the root system is able to reduce $\mathrm{K}$ in the soil solution, promoting release of $\mathrm{K}$ from the interlayers. Weber and Grimme (1986) suggested that one year of intensive cropping with ryegrass was approximately equivalent to $10-15$ years of normal cropping in the field. However the results of the pot experiment can be used as a guide in assessing the field situation.

Since available $\mathrm{K}$ does not fully describe $\mathrm{K}$ supplying power of the soils, soil types and $\mathrm{K}$ buffer power must also be taken into account when planning any application of $\mathrm{K}$ to the soil in the interest of fertilizer efficiency and economy.

\section{Acknowledgements}

PROCALFER-AID provided some financial support for this research. We wish to thank $\mathrm{J}$ M $\mathrm{V}$ Silva and $\mathrm{J} \mathrm{L}$ Ahlrichs in the identification of clay minerals. 


\section{References}

Adams F 1974 Soil solution. In The Plant Root and its Environment. Ed. E W Carson. pp 441-482. University Press of Virginia, Charlottesville.

Alves J A 1968 Fertilização do trigo. Revista Agronómica 31 (Tomos I e II): 1-10.

Alves J A, Nogueira M G B, Santos A D and Tavares M M S 1979 Fertilização Mineral e Correcção do Solo. I. Fertilização Mineral. Direç̧ão Geral dos Serviços Agrícolas III Plano de Fomento (1968-1973), Lisboa.

Binnie R R and Barber S A 1964 Contrasting release characteristics of potassium in alluvial and associated upland soils of Indiana. Soil Sci. Soc. Am. Proc. 28, $387-390$.

Cooke G W 1982 Fertilizing for Maximum Yield, 3rd ed. Macmillan, New York, 465 p.

Doll E C, Mortland M M, Lawton K and Ellis B G 1965 Release of potassium from soil fractions during cropping. Soil Sci. Soc. Am. Proc. 29, 699-702.

Feigenbaum S and Levy R 1977 Potassium release in some saline soils of Israel. Geoderma 19, 159-169.

Knuden D, Peterson G A and Pratt P F 1982 Lithium, sodium and potassium. In Methods of Soil Analysis, Part 2, 2nd ed. Eds. A L Page et al. pp 225-246. American Society of Agronomy, Madison.

Niederbudde E A and Fischer W R 1980 Clay mineral transformations in soils as influenced by potassium release from biotite. Soil Sci. 130, 225-231.

Portela E A C 1989 Avaliação da Disponibilidade de Potássio em Solos de Trás-os-Montes. Universidade de Trás-osMontes e Alto-Douro, Vila Real. 220 p.

Rich C I 1968 Mineralogy of soil potassium. In Role of Potassium in Agriculture. Eds. V J Kilmer, S E Younts and N C Brady. pp 79-108. American Society of Agronomy, Madison.

Silva J M V 1983 Estudo mineralógico da argila e do limo de solos derivados de granitos e rochas básicas da região de Trás-os-Montes. Garcia de Orta (Estudos Agronómicos) $10,27-36$.

Sinclair A H 1979 Availability of potassium to ryegrass from Scottish soils. II. Uptake of initially nonexchangeble potassium. J. Soil Sci. 30, 775-783.

Steffens D 1986 Root system and potassium exploitation. In Nutrient Balances and the Need for Potassium. pp 97-108. International Potash Institute, Berne, Switzerland.

Talibudeen O and Dey S K 1968 Potassium reserves in British soil. II. Soils from different parent materials. J. Agric. Sci. Camb. 71, 405-411.

Weber M and Grimme H 1986 The K - supplying capacity of soils developed from loess before and after intensive cropping with ryegrass. pp 1006-1007. XIII Congress of International Soil Science, Hamburg.

Section editor: $M L$ van Beusichem 